Discussion Papers of the

Max Planck Institute for

Research on Collective Goods

Bonn 2019/2

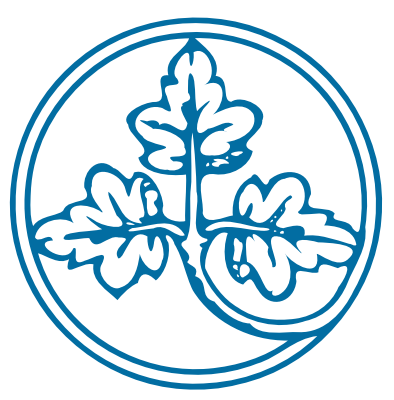

Tax Morale and Fairness

in Conflict

An Experiment

Christoph Engel

Luigi Mittone

Azzurra Morreale

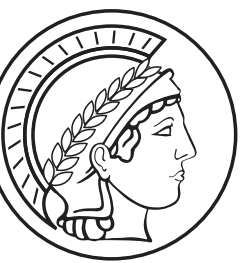




\section{Tax Morale and Fairness in Conflict An Experiment}

Christoph Engel / Luigi Mittone / Azzurra Morreale

February 2019 


\title{
Tax Morale and Fairness in Conflict An Experiment ${ }^{*}$
}

\section{Christoph Engel / Luigi Mittone / Azzurra Morreale}

\begin{abstract}
Arguably, for many citizens the perceived expected disutility from sanctions is smaller than the monetary gain from tax evasion. Nevertheless most people pay their taxes most of the time. In a lab experiment, we show that the willingness to pay taxes even absent enforcement is indeed pronounced. Yet voluntary compliance is reduced if participants learn that income is heterogeneous. The effect is driven by participants with the lowest income. The reduction obtains irrespective of the tax regime. If the tax is proportional to income, or progressive, participants become more skeptical about the willingness of participants with high income to comply.
\end{abstract}

JEL: C30, C91, D01, D02, D31, D63, D91, H26, K34, K42

Keywords: tax evasion, tax morale, heterogeneity, income inequality, lump sum tax, proportional tax, progressive tax, beliefs, path model

Helpful comments by Pascal Langenbach and Matthias Praxmarer are gratefully acknowledged. The experiment has been financed from the regular budget of the University of Trento. 


\section{Introduction}

Government can order citizens to pay taxes on their income. But for many sources of income, government has a hard time enforcing this obligation. Tax evasion is a serious concern. In economic terminology, the problem results from a principal agent relationship. There is moral hazard, chiefly because citizens can underreport income. If citizens are perfectly rational, in the sense of economic textbooks, government can solve the problem by threatening citizens with a sufficiently severe sanction when caught, provided it can credibly commit to sufficiently frequent audits (Allingham and Sandmo 1972). But not all citizens correctly anticipate the sanction. And arguably in many countries, at least for ordinary citizens, the expected cost of the sanction is below the amount they have to pay. If citizens maximize income, they would not pay (or pay less, in order not to appear suspicious). This sure happens. But in many countries, tax evasion seems to be much less frequent than profit maximization would predict. Apparently, tax morale is not imaginary.

Tax morale can have multiple reasons. Citizens have high valuation for public goods provided by government. They see paying taxes to their country as an expression of their national identity. They have picked up their attitude towards taxation through education, and do what they once have been taught. They overestimate the detection probability, or the severity of the sanction. They are concerned about additional disutility from loosing face in their local community. In this paper, we focus on another motive: citizens pay taxes because this is their duty. They follow the rule that is in force. In experiments, it has been shown that this propensity is surprisingly widespread (Kimbrough and Vostroknutov 2016).

In our experiment, we test rule following if the rule wants individuals to pay taxes. We investigate whether and in which ways the willingness to follow tax rules deteriorates in the face of heterogeneity. Heterogeneity faces government with a dilemma: if citizens care about not being disadvantaged, any tax regime is perceived as unfair by a relevant part of the population. They are liable to react by themselves evading taxes. Worse even: those privileged by the tax regime might anticipate that those disadvantaged will evade taxes, and might themselves evade taxes in response.

We compare a tax that is the same for everybody (a lump sum) with a tax that is proportional to the individual's income (a flat tax), and a tax that is progressive. All three schemes not only exist. They all resonate with characteristic fairness norms. A uniform tax implements equality of the absolute tax burden. A proportional tax creates equality of the relative tax burden. If individuals experience decreasing marginal utility of income, an (appropriately designed) progressive tax creates equality of the utility loss.

Tax rules not only affect the tax burden. They also, mechanically, create or reduce inequality of income. As equality preferences are pronounced, this could aggravate the problem.

Moreover, as one of us has shown in an earlier experiment, rule following is sensitive to information about the rule following of one's peers (Desmet and Engel 2017) (also see 
Bicchieri and Xiao 2009). This suggests that the socially beneficial effect of tax morale on an individual is conditional on her knowledge or expectations about the tax morale of her peers, which might, in turn, be affected by the perceived fairness of the tax regime.

We test theoretical predictions in the lab. Each of 20 periods, participants receive low, medium or high income. For each participant, the income is held constant throughout the experiment. During the first 10 periods, participants are on their own. They learn that there is a rule that wants them to pay a defined amount in taxes. During the first 10 periods, participants only know about the expected payment, not how it is calculated. This part of the experiment allows us to study rule following as a determinant of tax morale. The requested tax is held constant throughout the experiment. Yet in period 11, at the start of the main experiment, participants learn that they are part of a randomly composed group of three, and that the requested tax results from a tax regime that is either uniform, proportional to income, or progressive. In period 11, we thus make the fairness problem visible. There is no audit and, consequently, no sanction for tax evasion. There is also no feedback about taxes paid by other group members.

Participants pay substantial amounts of taxes. Rule following is a driver of tax morale. Yet if the fairness problem becomes visible, tax payments go down by $16 \%$. This effect is driven by participants who now know they have low income. Interestingly, on average participants do not pay more taxes if the regime is in their favor, and less taxes if the regime is in favor of another part of the population. Yet we do find these intuitive differences if we condition tax declarations on beliefs about choices of participants with high income. Irrespective of income, a direct effect (the tax regime is favorable or unfavorable) and an indirect effect (the tax regime is expected to decrease or increase tax declarations of individuals with high income) cancel out.

The remainder of the paper is organized as follows. In section 2, we relate the paper to the literature and define our contribution. In section 3 , we introduce the design of the experiment. In section 4, we report results. Section 5 concludes with discussion.

\section{Contribution}

Tax evasion is notoriously difficult to observe in the field. Also self-report data, and classifications by tax officers, do not significantly correlate with choices elicited in the lab (Elffers, Robben et al. 1992). These observations have spurred a very active experimental literature (for (partial) surveys see Torgler 2002, Alm and Jacobson 2007, Blackwell 2007, Kirchler 2007, Torgler 2007, Alm 2012, Hallsworth 2014, Pickhardt and Prinz 2014, Slemrod 2016). We follow this tradition and implement the canonical design: in every period participants receive a constant income. Income is liable to tax, but participants have the opportunity to underreport. Regularly, a substantial fraction of participants do (see, e.g. Doerrenberg and Duncan 2014b). Interest is in the determinants of this decision. 
Earlier experiments have shown that tax evasion increases in income (Becker, Büchner et al. 1987, Anderhub, Giese et al. 2001); in the tax rate (Alm, Jackson et al. 1992, Kleven, Knudsen et al. 2011) (but see Anderhub, Giese et al. 2001), and especially in reaction to an increase in the tax rate (Bernasconi, Corazzini et al. 2014); if the tax regime changes from proportional to progressive tax (Heinemann and Kocher 2013). All of these findings suggest that, in a homogenous population, tax evasion is least pronounced if the tax is flat, and most pronounced if the tax is progressive. Note however that, after the fall of the iron curtain, some of the successor states to Czechoslovakia, the USSR, and Yugoslavia, have introduced flat tax, while others have not. This difference has not significantly affected the overall rate of tax evasion (Filer, Hanousek et al. 2016).

The effect of individual morality and social norms on tax evasion is debated. Some experiments do not find a significant effect (Alm, McClelland et al. 1992), or find that it is only present in interaction with explicit sanctions for underreporting (Alm, Sanchez et al. 1995). Choices in an unframed gamble do not predict tax evasion when there is some risk of audit (Baldry 1986, but see Mittone 2006). When framing the payment as a tax, there is more evasion than with a neutral frame (Jacobsen and Piovesan 2014). Making the immorality of tax evasion salient has an effect, while making the illegality salient has not (Blaufus, Hundsdoerfer et al. 2016) (also see Bott, Cappelen et al. 2017). Knowing that this will put the willingness to pay taxes to a harder test, we frame our experiment as one about taxation.

For our research question, experiments are particularly relevant that induce heterogeneity. Spicer and Becker (1980) implement different tax rates for otherwise equal participants. Those with the highest tax burden evade most. Bazart and Bonein (2014) expose participants to an asymmetry in the tax rate, to social information about tax evasion by others, or both. Social information ("horizontal reciprocity") and their combination with "vertical reciprocity" significantly reduce reported income. Castro and Rizzo (2014) classify participants by their performance in a real effort task, which determines their earnings in the main experiment. If low performers have to pay high taxes ("vertical inequity") there is no significant difference in tax evasion. There is if the tax burden is arbitrarily determined, with no correlation to performance ("horizontal inequity"). Heinemann and Kocher (2013) have individuals participate in a repeated game. Income is partly related to measured ability, and partly stochastic. For 10 periods they either implement proportional or progressive tax. After 10 periods there is a regime change. Those who lose from the reform evade more taxes. Overall a shift to progressive taxation increases tax evasion. Participants with lower earning ability tend to evade more taxes (Doerrenberg and Duncan 2014a). ${ }^{1}$ There are two related findings with homogenous populations: there is no significant difference between the evasion of earned and assigned income (Durham, Manly et al. 2014). Tax evasion increases in the cost of effort (Bühren and Kundt 2014).

1 Also see the survey instrument by Jimenez and Iyer (2016). They find that „perceived fairness“, operationalized as a latent variable in a structural model, predicts tax compliance. 
We make four contributions to this literature: (1) we investigate whether, in a heterogeneous population, there is a systematic relationship between income brackets and tax evasion: are those with high income most likely to evade a progressive tax, those with average income most likely to evade a proportional tax, and those with low income most likely to evade a uniform tax? (2) Are descriptive norms (beliefs about choices) biased by individual income? (3) Is tax evasion more pronounced in a heterogeneous population, and is this effect driven by the income brackets disadvantaged by the respective tax regime? (4) Do those privileged by the tax regime anticipate that those disadvantaged will react with tax evasion?

This last step of our argument partly builds on earlier findings about the social dimension of tax evasion. Many find that there is more tax evasion if others underreport income (Wakolbinger and Haigner 2009, Bazart and Bonein 2014, Blaufus, Bob et al. 2014, Lefebvre, Pestieau et al. 2015). Honest taxpayers are even willing to finance a fund that fights tax evasion (Bazart and Bonein 2017). However in Fortin, Lacroix et al. (2007) participants evade less taxes the more their peers evade, and vice versa. Informing individuals about the prevalence of tax evasion does not increase their declared tax morale, while stressing reciprocity does (Doerrenberg and Peichl 2017). Social norms are a stronger safeguard against collusive, rather than individual tax evasion (Abraham, Lorek et al. 2017).

Tax evasion decreases the more public goods participants receive "in exchange" for their taxes (Alm, Jackson et al. 1992, Alm, McClelland et al. 1992), especially in terms of transfer income (Becker, Büchner et al. 1987). However Güth, Strauß et al. (2002) do not find that tax evasion reacts to induced changes in the effectiveness of a state pension system. Tax evasion decreases if participants know that tax income will be used to support other participants (Bosco and Mittone 1997), or for a worthy cause, like research or a well-regarded charity (Doerrenberg 2015). As we refrain from deterring tax evasion with a sanction, we exploit these earlier findings to make a floor effect less likely. We tell participants that the tax revenue will be used for another, unrelated experiment.

When tax returns are partly prefilled, the fact that deductions must be explicitly added reduces the amount of deductions claimed (Kotakorpi and Laamanen 2016, Fochmann, Müller et al. 2018) (also see Kleven, Knudsen et al. 2011, Gillitzer and Skov 2016), which can be interpreted as a default effect (see only Johnson and Goldstein 2003, Bechtold 2010). We exploit these findings to combat a floor effect. The normative tax report is prefilled, but participants are free to adjust the report.

Besides the substantive we also make a methodological contribution to the literature on tax evasion. We show that questions of tax morale can be meaningfully studied experimentally without the threat of sanctions. This makes the design of the experiment, and hence the identification of behavioral effects, much cleaner. 


\section{Theory}

If an individual $\boldsymbol{i}$ earns income $\boldsymbol{e}_{\boldsymbol{i}}$ that is subject to tax $\boldsymbol{t}_{\boldsymbol{i}}$, her profit is given by

$$
\pi_{i}=e_{i}-t_{j}(1)
$$

If there is no sanction and the individual maximizes profit, she will not pay taxes. This prediction is independent of the tax regime. This gives us

Hypothesis 1: Participants evade taxes, no matter which tax regime is in place.

Earlier experiments have demonstrated the willingness of individuals to follow (even arbitrary) rules (Kimbrough and Vostroknutov 2016). This behavioral regularity can be captured by disutility $\gamma_{i}$ from paying less taxes than the norm $\hat{\boldsymbol{t}}_{\boldsymbol{j}}$, and hence utility as in (2).

$$
u_{i}=\pi_{i}-\gamma_{i} \max \left\{\hat{t}_{i}-t_{i}, 0\right\}
$$

Provided $\gamma_{i}>1$, the individual pays the requested tax $\hat{t}_{i}$. This prediction is also not conditional on the tax regime, which gives us

Hypothesis 2: Participants pay the requested tax, no matter which tax regime is in place.

In the next step, we introduce the perceived fairness of the tax regime. We characterize the regime that this individual considers to be perfectly fair by $\tilde{t}_{i}$ and posit

$$
u_{i}=\pi_{i}-\gamma_{i} \max \left\{\hat{t}_{i}-t_{i}, 0\right\}-\delta_{i} \max \left\{\hat{t}_{i}-\tilde{t}_{i}, 0\right\}
$$

Hence this individual suffers disutility $\boldsymbol{\delta}_{\boldsymbol{j}}$ that is the more pronounced the more the requested tax $\hat{t}_{i}$ exceeds the tax $\tilde{t}_{i}$ that this individual considers fair. The bigger the gap $\hat{t}_{i}-\tilde{t}_{i}$, and the stronger the disutility $\delta_{i}$, the more demanding $\gamma_{i}$. This yields

Hypothesis 3: If participants know that income is heterogeneous, they declare less income.

We consider three characteristic fairness norms. They correspond to three characteristic tax regimes $\tilde{t}$. If $t_{i}=t, \forall i$, the absolute tax burden is held constant. If $t_{i}=\tau e_{i}$, with tax rate $\tau<\mathbf{1}$, the relative tax burden is held constant. Finally if $t_{i}=\tau e_{i}^{x}$ and progression factor $\boldsymbol{x}>\mathbf{1}$ chosen appropriately, disutility from paying taxes is held constant, provided individuals exhibit decreasing marginal returns from income. Capturing this latter possibility requires rewriting (3) as

$$
u_{i}=\pi_{i}^{y}-\gamma_{i} \max \left\{\hat{t}_{i}-t_{i}, 0\right\}-\delta_{i} \max \left\{\hat{t}_{i}-\tilde{t}_{i}, 0\right\}
$$

with $y \leq \mathbf{1}$ allowing for utility from income to be concave. 
We consider a society of three individuals $I, m h$ who have low, medium and high income, respectively. We fix $\boldsymbol{e}_{\boldsymbol{m}}$, and let $\boldsymbol{e}_{\boldsymbol{q}}=\boldsymbol{e}_{\boldsymbol{m}}-\boldsymbol{s}$, and $\boldsymbol{e}_{\boldsymbol{h}}=\boldsymbol{e}_{\boldsymbol{m}}+\boldsymbol{s}$, so that $\boldsymbol{s}$ captures the spread of incomes. If the (desired) tax revenue is held constant, individual $\boldsymbol{m}$ is indifferent between uniform and proportional tax, but has a lower income and hence utility with progressive tax. Individual $/$ has the lowest income with uniform tax, a higher income with proportional tax, and the highest income with progressive tax. For individual $\boldsymbol{h}$ the opposite ranking holds. The bigger $\boldsymbol{s}$, the more pronounced these income effects. We expect subjective fairness norms to be self-serving (Konow 2000, Konow 2003). For $\boldsymbol{l}$ and $\boldsymbol{h}$, the preferred fairness norm is straightforward. Individual $\boldsymbol{m}$ does not want progressive tax, and will likely not be opposed to proportional tax as a "fair" compromise between the interests of all individuals.

From these arguments we derive

\section{Hypothesis 4:}

a) individuals with low income declare less income if the regime is uniform or proportional.

b) individuals with medium income declare less income if the regime is progressive.

c) individuals with high income declare less income if the regime is proportional or progressive.

Taxes reduce income. This is why taxes, mechanically, moderate the relative after tax income. A rich experimental literature shows that individuals are sensitive to income equality. We follow the canonical model by Fehr and Schmidt (1999) and extend (4) to get

$$
u_{i}=\pi_{i}^{y}-\gamma_{i} \max \left\{\hat{t}_{i}-t_{i}, 0\right\}-\delta_{i} \max \left\{\hat{t}_{i}-\tilde{t}_{i}, 0\right\}-\alpha_{i} \sum_{k=2}^{N} \max \left\{\pi_{k}-\pi_{i}, 0\right\}
$$

This yields

Hypothesis 5: Unless the tax is progressive, individuals with low income comply least with the tax rule.

In the final step, we make rule following conditional on the rule following of others. Formally, we let

$$
\gamma_{i}=1-\rho_{i} \sum_{k=2}^{N} \max \left\{\hat{t}_{k}-t_{k}, 0\right\}
$$

Hence we assume that the willingness to pay the required taxes decreases in the number $k$ of peers who evade taxes, and in the degree $\hat{t}_{k}-t_{k}$ by which they do. Factor $\rho_{i}<\frac{1}{N-1}$ determines how strongly individual $\boldsymbol{i}$ reacts to tax evasion by her peers. Now as a rule, one individual cannot observe how much income others report. This implies that, in (6), she must replace $t_{i}$ with $E\left(t_{i}\right)$.

In principle, the resulting strategic uncertainty transforms decisions to pay taxes into a strategic game. If all individuals were perfectly foresightful (were level k reasoners), by the logic 
of the beauty contest we would have to expect $\gamma_{j} \rightarrow 0$ (Arad and Rubinstein 2012). The exact parameter would depend on $\rho_{i}$ and the individual's idiosyncratic beliefs about $\rho_{-i}$. If these parameters are sufficiently strong, in the Bayes-Nash equilibrium the socially beneficial force of the willingness to follow rules is completely neutralized. Yet in another experiment involving clashing fairness norms, one of us has shown that there is a surprisingly strong match between the individuals' own fairness assessment and their beliefs about the choices of others (Bar-Gill and Engel 2018). In the language of models of foresightedness, such individuals can be characterized as level 0 types. This lets us expect

Hypothesis 6: The more individuals are skeptical about others paying taxes, the less taxes they pay themselves.

\section{Design}

Our design matches the theory. Each of 20 periods, participants receive low (5), medium (10) or high income (15). For each participant, the income is held constant throughout the experiment. During the first 10 periods, participants are on their own. They learn that there is a rule that wants them to pay tax $t_{k}$. During the first 10 periods, participants only know about the expected payment, not how it is calculated. The requested tax is held constant throughout the experiment. Yet in period 11, at the start of the main experiment, participants learn that they are part of a randomly composed group of three, and that the requested tax results from a tax regime that is either the same for everybody, proportional to income, or progressive. In period 11 , we thus make the fairness problem visible. There is no audit and, consequently, no sanction for tax evasion. There is also no feedback about taxes paid by other group members.

We are interested in the effect of heterogeneity in income on the willingness to pay taxes. We want to isolate the impact of this heterogeneity on the perceived fairness of tax regimes. This is why we have opted against a real effort task. This avoids a confound with fairness of desert (cf. Gill and Stone 2010).

The tax revenue is not distributed back to participants (the same way as, e.g., in Bazart and Bonein 2014). This feature is meant to avoid a confound with a preference for a specific public good, and for redistribution in particular. We inform participants that the tax revenue is used to finance another experiment.

We want to isolate the effect of heterogeneity in income, and of competing fairness norms, on the willingness to pay taxes merely because paying taxes is the norm. This is why we inform participants that their declarations will not be audited. Findings can therefore not be driven by aversion against the risk of a fine. Sanctions can also not serve as a complement to the propensity for rule following (cf. Engel 2014). 
We use two elements of the design to make a floor effect unlikely. We fix the tax revenue at $20 \%$ of the expected total income of the group. Consequently the tax burden is not heavy. Moreover we exploit the power of defaults (Johnson and Goldstein 2003, Bechtold 2010). We implement a scheme that has been shown to increase truthful reporting: we prefill the tax declaration (Kleven, Knudsen et al. 2011, Gillitzer and Skov 2016, Kotakorpi and Laamanen 2016, Fochmann, Müller et al. 2018). We use a wording similar to practical applications:

"To facilitate your reporting, in each round, you will be shown the tax you are required to pay. However, you are free to change the amount as you like”.

We manipulate the tax regime. The total group income is $5+10+15=30$, which is why the target tax revenue is 6 . In the lump sum regime, each participant is supposed to pay $t=2$. In the proportional regime, each participant is supposed to pay $t_{k}=\tau e_{k}=.2 * e_{k}$. Hence we set $t_{l}=1, t_{m}=2, t_{h}=3$. To design the progressive regime, we exploit the fact that a decreasing marginal return of income is isomorphic to risk aversion. We specialize on

$$
u=\pi^{y}=\frac{\pi}{1-r}(8)
$$

which is constant relative risk aversion. The canonical paper by Holt and Laury (2002: 1649) finds that individuals are most likely to be moderately risk averse, with $r \in[-41,68] .{ }^{2}$ To facilitate the exposition, we do not choose the midpoint ( $r=.545$ ), but $r=.5$. The utility function defined by (8) is almost linear for higher levels of income, but diverges profoundly from linear utility near the origin. If we were to calculate the progressive tax based on untransformed payoffs, it would be almost perfectly identical with proportional tax. Progressive tax however differs substantially if we calculate it assuming that only income above a subsistence level of 3 should be liable to tax. We calculate the resulting tax the following way: we keep the total (expected) tax revenue fixed at 6; we define taxes such that each individual suffers the same utility loss. For details see the appendix. Table 1 summarizes our treatments.

\begin{tabular}{|l|c|c|c|c|c|c|c|}
\hline & $\begin{array}{c}\text { gross } \\
\text { income }\end{array}$ & $\begin{array}{c}\text { lump sum } \\
\text { tax }\end{array}$ & $\begin{array}{c}\text { utility } \\
\text { loss }\end{array}$ & $\begin{array}{c}\text { proportional } \\
\text { tax }\end{array}$ & $\begin{array}{c}\text { utility } \\
\text { loss }\end{array}$ & $\begin{array}{c}\text { progressive } \\
\text { tax }\end{array}$ & $\begin{array}{c}\text { utility } \\
\text { loss }\end{array}$ \\
\hline low & 5 & 2 & $100 \%$ & 1 & $29.3 \%$ & .571 & $15.5 \%$ \\
\hline medium & 10 & 2 & $15.5 \%$ & 2 & $15.5 \%$ & 2 & $15.5 \%$ \\
\hline high & 15 & 2 & $8.7 \%$ & 3 & $13.4 \%$ & 3.429 & $15.5 \%$ \\
\hline
\end{tabular}

Table 1

Treatment Characteristics

utility loss is in \% of utility without tax

utility loss is calculated assuming a tax free income of 3

The tax experiment is embedded in a series of pre- and post-experimental tests. They are meant to give us more scope for isolating the effect of clashing fairness norms. Participants know that the experiment has multiple parts, but that later parts will only be introduced after

2 This is the mode for real choices that are repeated, as well as for hypothetical choices. 
former parts have been finished. To preserve the independence of individual choices, feedback from all parts of the experiment is withheld until the end of the entire experiment. The sequence is as follows:

1. Tax declarations without information about group composition and tax scheme

2. Tax declarations with information about group composition and tax scheme

3. Normative beliefs

4. Descriptive beliefs

5. Risk preferences

6. Social value orientation

7. Demographic information

The first part of the experiment exposes participants to the same design as the main experiment. Participants take 10 subsequent decisions, on the identical choice problem. Their period income is the same as in the main experiment. Hence for participants who have income of 5 in the main experiment also have this income in the first part. Likewise for participants with an income of 10 or 15 . The stated tax rate is the same as in the main experiment. The only difference between the first and the second part of the experiment is information about group composition, and about the design of the tax scheme. In the first part, participants do not know that other participants have a different income. They also do not know how the tax rate has been calculated. This first part of the experiment serves two related purposes. We gain an individual specific measure for the willingness to follow a costly rule, and we have the possibility to complement the between subjects design with a within subjects comparison: in which ways is the decision to evade taxes influenced by the tax regime, as interacting with an individual's relative income?

Hypothesis 4 expects tax evasion to be related to the perceived fairness of the tax regime. We use the standard measure by Krupka and Weber (2013) to measure participants' beliefs about injunctive norms. We ask for an estimate of social acceptability, separately per endowment and percent of requested tax, in steps of $10 \%$.

Hypothesis 6 expects choices to be influenced by (descriptive) beliefs. ${ }^{3}$ To learn whether this is true, we ask participants how much participants with income 5,10 and 15 have declared on average. At the end of the experiment, one of these three levels is randomly selected to be payoff relevant. If any of the estimates (rounded to the next integer) is precisely correct, the participant receives 20 ECU. If the estimate is no further than 1 below or above the correct number, she receives 10 ECU.

3 The distinction between descriptive and injunctive beliefs has originally been proposed by Robert Cialdini, as part of his focus theory of normative conduct (Cialdini, Kallgren et al. 1991). 
Our design deliberately excludes sanctions for tax evasion. Per se, risk is therefore not relevant for choices. Yet as we mention in the theory section, the decreasing marginal utility of income is isomorphic to risk aversion. We exploit this isomorphism and estimate risk aversion, using the standard measure by Holt and Laury (2002). This gives us an individual specific parameter for the curvature of the utility function.

Our model encompasses the mechanical effect of the tax regime on the distribution of income. We measure the individual sensitivity to inequity using the standard measure by Murphy and Ackermann (2014).

As descriptive beliefs about the compliance of participants with high income turn out to be the only variable from a post-experimental test that explains tax compliance, in the analysis we focus on this control variable.

We have run the experiment in the Cognitive and Experimental Economics Laboratory of Trento University. The experiment has been implemented in the software oTree (Chen, Schonger et al. 2016). 54 students of various majors have participated, 18 in each treatment. Half of the participants have been female. Participants on average have earned $12.72 €$ from the experiment (14.94 \$ on the first day of the experiment), plus a show up fee of $3 €$. Differences in endowment have translated into differences in earnings: endowment 5: average profit from the experiment 7.95 €; endowment 10: $12.55 €$; endowment 15: $17.65 €$.

\section{Results}

Figure 1 summarizes results from the main experiment. The dependent variable is the percent of the requested tax individuals with a certain endowment (one of the three panels) and subject to a certain tax regime (color) on average pay in the respective period. Up till period 10 (the vertical line) participants do not know that they are part of a group of three, and how the requested tax has been calculated.

Visibly we reject $\mathbf{H}_{\mathbf{1}}$. Irrespective of tax regime and endowment, participants declare substantial amounts of income, even if they have learned that they are part of an asymmetrically composed group. Only 8 of 54 participants never declare any taxes in the main experiment. Overall, they on average declare $50.94 \%$ if the tax is uniform, $28.67 \%$ if the tax is proportional, and $32.33 \%$ if the tax is progressive. This is significantly different from $0 .{ }^{4}$ We also reject $\mathbf{H}_{\mathbf{1}}$ separately for the lump sum tax and endowment $5(\mathrm{p}<.0001){ }^{5}$ endowment $10(\mathrm{p}<$

4 The appropriate statistic is the constant of a regression with compliance as the dependent variable. Compliance is defined as declared tax / requested tax, and hence normalized over endowments. We capture dependence from the fact that participants make multiple choices by a participant random effect. Note that there is no dependence at the group level, as we do not give participants feedback about the choices made by other group members. Hence there is no need for a further random effect at the group level. All regressions are linear. We have 540 choices from the main experiment (10 per participant). 
$.0001)$ and endowment $15(\mathrm{p}=.001)$; for proportional tax and endowment $10(\mathrm{p}=.002) ;{ }^{6}$ for progressive tax and endowment $5(\mathrm{p}=.003)$, endowment $10(\mathrm{p}=.001)$, and endowment $15(\mathrm{p}$ $<.0001)$.
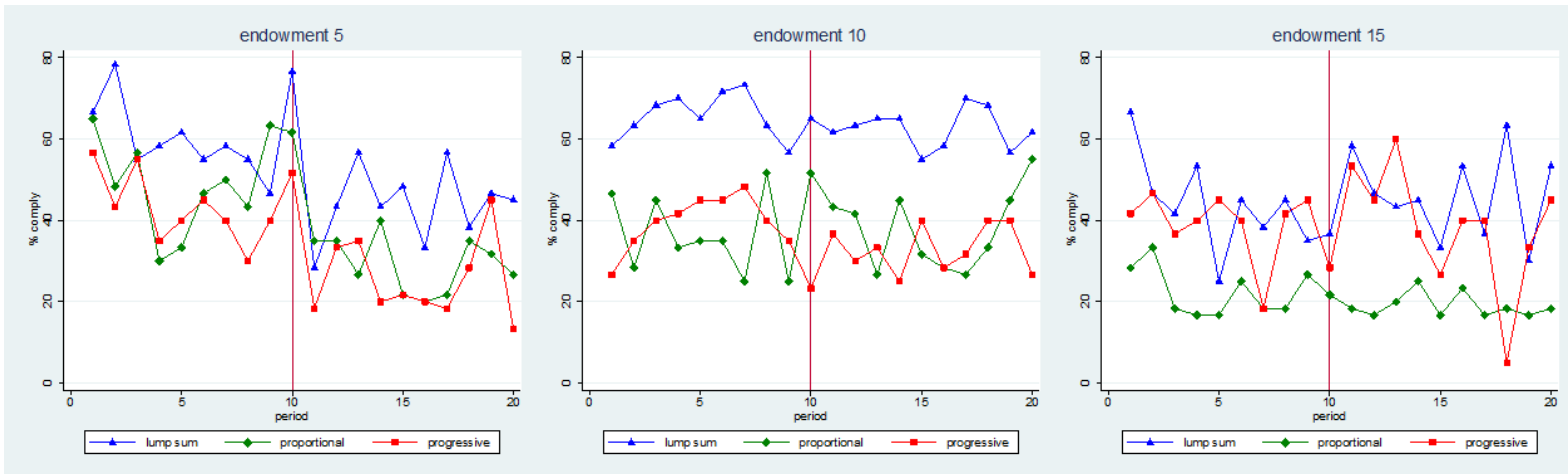

\section{Figure 1}

Tax Compliance

$\mathrm{dv}$ : \% of requested tax

On the other hand, Figure 1 shows that tax compliance is far from perfect. We reject that compliance is $100 \%$ both overall $(\mathrm{p}<.0001)^{7}$ and separately for each tax regime and endowment $(\mathrm{p}=.0003$ for lump sum tax and endowment $10, \mathrm{p}=.0002$ for lump sum tax and endowment 15 , and $\mathrm{p}<.0001$ for all other combinations of tax regime and endowment). ${ }^{8}$ We thus also reject $\mathbf{H}_{\mathbf{2}}$.

Figure 1 suggests that tax morale is not only real, but that it carries over from a situation where participants are not aware of the conflict with fairness to a situation where this conflict has become visible: tax declarations essentially stay at the same level in period 11, even if participants with a certain endowment happened to have very high tax morale (as those with endowment 10 when the tax is uniform) or very low tax morale (as those with endowment 15 when the tax regime is proportional). Yet, irrespective of the tax regime, participants declare considerably less income if they learn that their income is the lowest in the group. This visual impression is corroborated by statistical analysis. Overall, making the fairness concern visible reduces compliance by $16 \%$ (Model 1 of Table 2). ${ }^{9}$ Yet as model 2 shows, this effect is exclusively driven by participants with the lowest endowment 5 . The interactions between social information and endowments 10 or 15 neutralize the main effect of social information. ${ }^{10}$

For treatment proportional and endowment 5 , the constant is only weakly significant, $\mathrm{p}=.053$. For treatment proportional and endowment 15 , the constant is not significantly different from 0 . See the Appendix for the imbalance in the composition of the type space.

$7 \quad$ Wald test of the point prediction after the regression reported in footnote 4.

$8 \quad$ Wald tests of the point prediction after the regressions reported in footnote 5.

$9 \quad 7.111 / 44.426=.160$.

10 Net effects of social information plus the interaction term are not significantly different from 0 for endowment $10(\mathrm{p}=.2813)$ and endowment $15(\mathrm{p}=.9817)$. 


\begin{tabular}{|l|l|l|}
\hline & model 1 & model 2 \\
\hline social information & $-7.111^{\star \star \star}$ & $-18.667^{\star \star \star}$ \\
& $(1.423)$ & $(2.424)$ \\
\hline endow 10 & & $\begin{array}{l}-4.500 \\
(8.315)\end{array}$ \\
\hline endow 15 & & $\begin{array}{l}-16.889^{\star} \\
(8.315)\end{array}$ \\
\hline social information * endow 10 & & $\begin{array}{l}16.056^{\star \star \star} \\
(3.427)\end{array}$ \\
\hline social information * endow 15 & & $\begin{array}{l}18.611^{\star \star \star} \\
(3.427)\end{array}$ \\
\hline cons & & $51.556^{\star \star \star}$ \\
& $44.426^{\star \star \star}$ & $(7.203)$ \\
\hline $\mathrm{N}$ obs & $(5.372)$ & 1080 \\
\hline $\mathrm{N}$ uid & 1080 & 54 \\
\hline
\end{tabular}

Table 2

Conflict between Tax Morale and Fairness

linear models with random effects for individuals dv: compliance (declared / requested tax)

social information: dummy that is 1 if data is from periods $11-20$ endow 10 / 15: endowments of 10 or 15 ECU per period standard errors in parenthesis

*** $\mathrm{p}<.001, * * \mathrm{p}<.01, * \mathrm{p}<.05{ }^{+} \mathrm{p}<.1$

Another way of making the point follows from tax revenue. If all participants declare all taxable income, tax revenue should be 360 in each treatment of the main experiment. ${ }^{11}$ It actually is 183.4 when the tax is lump sum, 97 when it is proportional, and 127.69 when it is progressive. This is always less than tax revenue if participants do not know that they are part of a group, and how the tax is calculated. Then tax revenue is 204 if the tax is uniform, 115.3 if it is proportional, and 139.43 if it is progressive.

We thus establish the conflict between tax morale and fairness that we had expected in $\mathbf{H}_{3}$. We also show that this conflict is most pronounced for participants with low income, as we had expected in $\mathbf{H}_{\mathbf{6}}$. We conclude

Result 1: If participants are part of a group with heterogeneous income, tax declarations are lower. Irrespective of the tax regime, this effect is driven by participants with the lowest income.

In $\mathbf{H}_{\mathbf{4}}$ we had expected a direct effect of perceived fairness on tax compliance. If the tax regime is to the detriment of one's income bracket, tax evasion should be more pronounced. Both Figure 1 and Model 1 of Table 3 show that we do not have support for this hypothesis. In this regression, the main effects of the tax regime being proportional or progressive measure the effect of a difference in tax regime for participants with endowment 5 . The main effects of endowment 10 or 15 measure the effect of the tax being lump sum for participants

11 There are 6 groups per tax regime. Each of them makes choices in 10 periods. If all declare income correctly, the tax revenue from the group is 6 , irrespective of the tax regime. 
with higher income. The interaction effects measure the effects of the remaining income/tax regime combinations. All main and interaction effects are insignificant.

\begin{tabular}{|l|l|l|}
\hline & model 1 & model 2 \\
\hline endow 10 & 18.500 & $25.529^{\star *}$ \\
& $(13.161)$ & $(10.150)$ \\
\hline endow 15 & 2.333 & $30.450^{\star *}$ \\
& $(13.161)$ & $(10.520)$ \\
\hline proportional & -14.667 & $23.604^{\star}$ \\
& $(16.934)$ & $(10.845)$ \\
\hline progressive & -18.667 & $23.040^{\star}$ \\
& $(16.934)$ & $(10.975)$ \\
\hline endow 10 * proportional & -10.167 & $-36.722^{*}$ \\
& $(18.612)$ & $(14.571)$ \\
\hline endow 10 * progressive & -10.667 & $-35.191^{*}$ \\
& $(18.612)$ & $(14.534)$ \\
\hline endow 15 * proportional & -12.667 & $-32.192^{\star}$ \\
& $(18.612)$ & $(13.469)$ \\
\hline endow 15 * progressive & 10.833 & $-37.903^{*}$ \\
& $(18.612)$ & $(15.150)$ \\
\hline belief 15 & & $.913^{\star \star \star}$ \\
& & $(.101)$ \\
\hline cons & $44.000^{\star \star \star}$ & $-23.949^{\star}$ \\
& $(11.974)$ & $(9.942)$ \\
\hline $\mathrm{N}$ obs & 540 & 540 \\
\hline $\mathrm{N}$ uid & 54 & 54 \\
\hline
\end{tabular}

Table 3

Determinants of Compliance in Main Experiment

linear models with random effects for individuals

dv: compliance (declared / requested tax)

endow 10 / 15: endowments of 10 or 15 ECU per period

belief 15: estimated compliance of all participants with endowment 15 in respective session standard errors in parenthesis

$* * * \mathrm{p}<.001, * * \mathrm{p}<.01, * \mathrm{p}<.05,^{+} \mathrm{p}<.1$

The picture clears when, in Model 2, we control for the belief about the choices of participants with high endowment. Now all expected main and interaction effects go through. We only find significant main and interaction effects though if we control for the belief about compliance by participants with high, not with medium or low income. Participants are thus influenced by their beliefs about the effect of the tax regime on others, as we had hypothesized in $\mathbf{H}_{6}$, but only about one group of the population. We conclude

Result 2: Conditional on their beliefs about the tax compliance of participants with high income,

a) participants with low income declare less income if the tax is a lump sum,

b) participants with medium or high income declare more income if the tax is a lump sum.

In Model 2 of Table 3 we show that beliefs are critical for treatment effects. In the structural model of Table 4 we go one step further. We simultaneously estimate the effect of treatments 
on compliance and on beliefs, and the effect of beliefs on choices. ${ }^{12}$ This has three advantages: we can see treatment effects on beliefs; indirect effects of treatment on compliance through effects on beliefs; and net (additive) effects of the respective direct and indirect effect.

Figure 2 represents our approach as a path model. ${ }^{13}$ In the second column of Table 4 (comply) we estimate the direct effect of endowments $e_{i}$, tax regime $\tau_{i}$ and the belief $b$ individual $i$ holds about the choices participants with endowment 15 , on the choices c individual i makes in each period t. We thus estimate paths (1), (2) and (5). In the third column (belief) we estimate the direct effects of endowments and tax regimes on beliefs about the choices participants with high endowments make. We thus estimate paths (3) and (4). In the fourth column (indirect effect), we report indirect effects of endowment and tax regime on choices, through the effect of beliefs on choices. We thus estimate multiplicative effects (of endowment or tax regime on beliefs, times the effect of beliefs on choices). In the path model, they are represented by the dashed red paths (6) and (7). In the last column (net effect) we report net effects, i.e. path (1) $+(6)$, and $(2)+(7)$, respectively. ${ }^{14}$

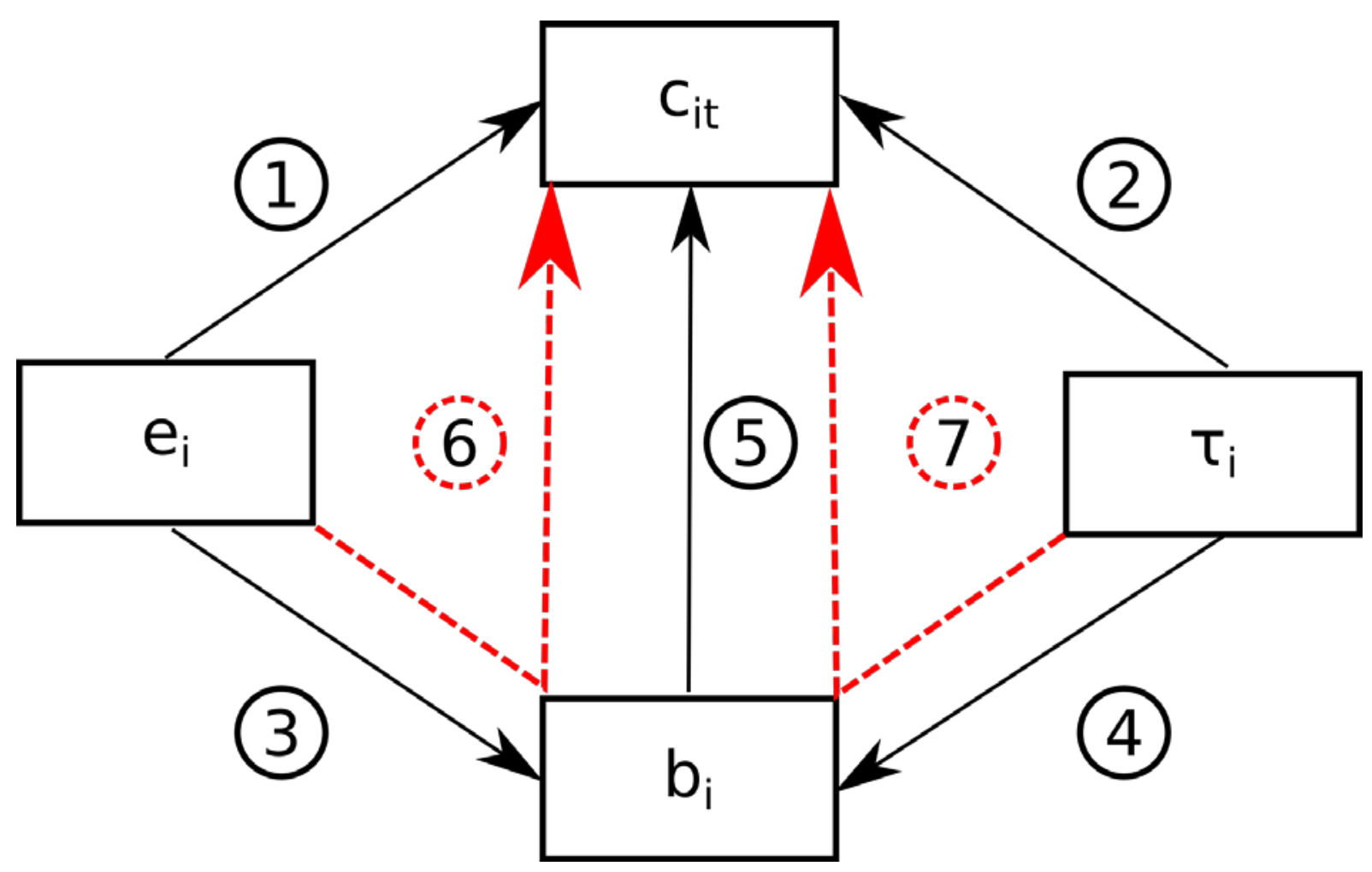

Figure 2

Path Model

12 Unsurprisingly, the model does not converge if, for both components, we estimate a random effect for groups, and another for individuals nested in groups; beliefs do not differ within individuals. We react by clustering standard errors at the highest level of dependence, i.e. groups.

13 To improve visibility, the figure drops the interactions between endowment and tax regime.

14 Standard errors and significance levels for the indirect and net effects are calculated using the delta method. 
We first see that not only choices react to treatment; so do beliefs. Actually whenever we find a positive treatment effect on compliance, the corresponding treatment effect on beliefs is negative, and vice versa (but not always significantly different from 0 ). If a participant has endowment 5 and the tax regime is proportional (main effect of treatment proportional), she is more skeptical about income declarations by those with endowment 15 . Likewise if the tax regime is progressive. Those with endowment 15 are more skeptical about income declarations of all participants with this endowment if the tax is uniform than the corresponding expectations of those with endowment 5 (main effect of endowment 15). Yet they have more optimistic beliefs about the income declarations of all participants with this endowment if the tax regime is progressive (interaction of endowment 15 with progressive taxation). Hence those with endowment 5 are overly pessimistic about compliance of others with higher endowments if the tax regime is not in their favor. Interestingly, if the tax is a lump sum, even those with endowment 15 are skeptical about compliance of others with the same endowment (effect of endowment 15 on beliefs).

Moreover, in a structural model we can test indirect (multiplicative) effects of treatment on choices through the effect of treatment on beliefs. These indirect effects are significant whenever the effect of our manipulation on beliefs is significant. Those with endowment 15 expect participants with this endowment to declare less income if the tax is uniform, compared with the estimate of this effect by those who have endowment 5 themselves (main effect of endowment 15 on beliefs). Through the significant positive effect of beliefs about choices of those with endowment 15 , the more skeptical belief translates into a substantial reduction in the income declaration these participants make themselves (indirect effect of endowment 15 on compliance). Vice versa if the endowment is 15 and the tax regime is progressive. If the tax regime is proportional or progressive and an individual's own endowment is 5 , she holds strongly negative beliefs about the compliance of participants with endowment 15 . This translates into a strong negative indirect effect on her own compliance (negative indirect effects of tax regime being proportional or progressive).

Most interestingly, we now understand why we cannot establish unconditional treatment effects: the direct effect of the tax regime on participants with a certain endowment, and the indirect effect of this manipulation on their beliefs about those with endowment 15 not only always have opposite sign. As the final column of table shows, direct and indirect effects always cancel out. Net effects are always insignificant. 


\begin{tabular}{|c|c|c|c|c|}
\hline & comply & belief 15 & indirect effect & net effect \\
\hline endow 10 & $\begin{array}{l}25.529 * \star \star \\
(4.967)\end{array}$ & $\begin{array}{l}-7.500 \\
(11.579)\end{array}$ & $\begin{array}{l}-7.029 \\
(4.280)\end{array}$ & $\begin{array}{l}18.500 \\
(14.217)\end{array}$ \\
\hline endow 15 & $\begin{array}{l}30.450^{\star \star \star} \\
(7.493)\end{array}$ & $\begin{array}{l}-30.000^{\star} \\
(14.642)\end{array}$ & $\begin{array}{l}-28.117^{\star} \\
(13.881)\end{array}$ & $\begin{array}{l}2.333 \\
(17.529)\end{array}$ \\
\hline proportional & $\begin{array}{l}23.604^{\star \star \star} \\
(5.728)\end{array}$ & $\begin{array}{l}-40.833^{*} \\
(16.925)\end{array}$ & $\begin{array}{l}-38.270^{\star} \\
(16.013)\end{array}$ & $\begin{array}{l}-14.667 \\
(18.037)\end{array}$ \\
\hline progressive & $\begin{array}{l}23.040^{\star *} \\
(7.424)\end{array}$ & $\begin{array}{l}-44.500^{\star *} \\
(13.190)\end{array}$ & $\begin{array}{l}-41.707^{\star *} \\
(13.378)\end{array}$ & $\begin{array}{l}-18.667 \\
(12.971)\end{array}$ \\
\hline endow 10 * proportional & $\begin{array}{l}-36.722^{\star \star \star} \\
(9.446)\end{array}$ & $\begin{array}{l}28.333 \\
(22.355)\end{array}$ & $\begin{array}{l}26.555 \\
(21.423)\end{array}$ & $\begin{array}{l}-10.167 \\
(24.147)\end{array}$ \\
\hline endow $10 *$ progressive & $\begin{array}{l}-35.191^{* *} \\
(10.124)\end{array}$ & $\begin{array}{l}26.167 \\
(22.941)\end{array}$ & $\begin{array}{l}24.524 \\
(17.870)\end{array}$ & $\begin{array}{l}-10.667 \\
(19.438)\end{array}$ \\
\hline endow 15 * proportional & $\begin{array}{l}-32.192^{\star} \\
(12.484)\end{array}$ & $\begin{array}{l}20.833 \\
(22.243)\end{array}$ & $\begin{array}{l}19.526 \\
(21.528)\end{array}$ & $\begin{array}{l}-12.667 \\
(27.676)\end{array}$ \\
\hline endow 15 * progressive & $\begin{array}{l}-37.903^{\star} \\
(15.622)\end{array}$ & $\begin{array}{l}52.000^{\star *} \\
(17.911)\end{array}$ & $\begin{array}{l}48.736^{\star \star} \\
(17.427)\end{array}$ & $\begin{array}{l}10.833 \\
(22.343)\end{array}$ \\
\hline belief 15 & $\begin{array}{l}.937^{\star \star \star} \\
(.093)\end{array}$ & & & \\
\hline cons & $\begin{array}{l}-23.949 * \star \\
(7.228)\end{array}$ & $\begin{array}{l}72.500^{\star \star \star} \\
(8.558)\end{array}$ & & \\
\hline $\mathrm{N}$ obs & \multirow{3}{*}{\multicolumn{4}{|c|}{$\begin{array}{l}540 \\
54 \\
18\end{array}$}} \\
\hline $\mathrm{N}$ uid & & & & \\
\hline $\mathrm{N}$ group & & & & \\
\hline
\end{tabular}

Table 4

Structural Model Explaining Choices with Treatment and Beliefs, and Beliefs with Treatment linear model with standard errors clustered at the group level

dvs: compliance rate in main experiment; estimated compliance rate of participants with endowment 15 indirect effect: of variable in question on compliance rate in main experiment, through beliefs net effect: of direct + indirect effect standard errors for indirect and net effects from delta method for variable names see legend of Table 3 standard errors in parenthesis $* * * \mathrm{p}<.001, * * \mathrm{p}<.01, * \mathrm{p}<.05,^{+} \mathrm{p}<.1$

We conclude

Result 3: Except if the tax is a lump sum and endowment is 10, the direct effect of the tax regime on compliance and its indirect effect through beliefs about compliance of participants with endowment 15 cancel out.

\section{Discussion}

Our experiment brings good and bad news for government that wants to finance public goods and redistribution from the tax revenue. The good news: even if individuals stand no chance to derive any personal benefit from how the tax revenue is used, and if they are perfectly protected from sanctions for tax evasion, most of them pay substantial amounts of taxes. Tax morale is real, even under these extreme conditions. The bad news: if income is known to be heterogeneous, tax morale deteriorates. In the experiment, income declarations are reduced by 
$16 \%$. This socially detrimental effect is driven by the fact that participants with low income comply less as soon as they are made aware of the heterogeneity of the population.

Now in industrialized societies, income brackets have very uneven size. If government is chiefly interested in the tax revenue, it might be tempted to react to the conflict between fairness and tax morale by targeting one of the income brackets specifically. If government is most concerned about tax payments from the largest part of the population, i.e. those with low income, it might want to introduce progressive taxation. If government is most concerned about tax payments from those with high income, it might want to introduce proportional or even a lump sum tax. Interestingly our experiment suggests that the choice of the tax regime is irrelevant for the tax revenue. Essentially, there is nothing government can do about the negative effect of fairness concerns on tax compliance. Whichever the income bracket, and whichever the tax regime, a direct effect and an indirect effect cancel out. The direct effect stems from respecting or neglecting the fairness concerns of the income bracket in question. The indirect effect stems from the expectations this income bracket holds about the effects of the tax regime in question on tax compliance by those with high income.

One may wonder whether we must qualify this statement, given tax revenue is higher if the tax is a lump sum, rather than proportional or progressive. Yet inspecting Figure 1 one sees that this effect is not driven by the tax regime, but by heterogeneity in our sample. Irrespective of their endowment (but most pronouncedly if the endowment was 10), those who later learn that the tax is a lump sum already comply more when they neither know that the population is heterogeneous, nor how the tax is calculated. This higher propensity to abide by the rules carries over to periods 11-20.

Our design does not make it possible to overreport income. Participants with endowment 15 lack a technology for actively redressing the equality balance by sharing income with participants randomly endowed with low income. Aversion to advantageous inequality does of course exist. Yet we do not see this as an important limitation. As we have reported, participants with endowment 15 on average even do not pay more than $44.83 \%$ of the requested tax if the tax regime is most to their advantage, as it is the same for everybody. They on average believe that, with this tax regime in place, participants with endowment 5 will only pay $26.67 \%$ of the requested tax. Hence they would have plenty of room for making final income more equal by declaring their own endowment more faithfully.

In our experiment, participants are sure that underreporting income will not have material consequences. But they know that the experimenter knows their income with certainty, the same as the income of all other participants. In other contexts, it has been shown that observability reduces dishonesty (Abeler, Nosenzo et al. 2016, Gneezy, Kajackaite et al. 2018). In the field, observability is more limited. We acknowledge this and caution against the possibility that the level of tax morale might be lower in the field. Yet we do see no reason why the effects of income inequality and tax regimes should be affected by observability. 
On the other hand, in our experiment income inequality results from a random draw. It has been shown that this increases dishonesty (Kajackaite 2018). In the field, income differences are at least partly due to differences in effort. This suggests that that levels of tax morale might be lower in our experiment than in the field. Possibly the effects of observability and of randomness on the level of tax morale cancel out.

Policymakers should take our main finding as liberating. They have to live with the (in the experiment rather modest) negative effect of fairness on tax morale. The choice of the tax regime can be driven by policy preferences, e.g. by a desire for indirect redistribution through differential tax burdens.

We find that only beliefs about tax compliance of participants with high endowment matter for tax compliance - for participants from all income brackets. This suggests that interventions aiming at compliance by individuals with high income pay a double dividend: government not only secures more taxes from individuals who most contribute to the budget; it indirectly also stabilizes the tax morale of the entire population.

Experiments are tools for isolating causal effects. The inevitable price for identification through random assignment to treatment is a loss in external validity. By design, the experiment is only analogous to the phenomenon in the field that one wants to understand. Our experiment is no exception to this rule. Yet when one wants to understand tax evasion, lab experiments have a big additional advantage: they allow to observe behavior that is otherwise obscured by a deep dark field. ${ }^{15}$ We nonetheless note the limitations inherent in our method. In our experiment, income is assigned, not earned (to exclude a confound with fairness of desert). Our participants are all students. Their attitude towards tax evasion might differ from the general population. The amount of income that is at stake is small. The tax rate is deliberately light. Participants are perfectly informed about income brackets in the population, and about the tax burden inflicted on each of these brackets. Underreporting income is the only potential source of tax evasion. Participants know that the experimenter perfectly observes their income. There is no audit and no sanction. Tax evasion choices are also not made public so that there is no cost of reputation.

No tax authority completely relies on tax morale. Even if the probability of audit is small, and the sanction for small amounts of tax evasion is not too severe, all taxpayers face at least a small risk of being sanctioned for tax evasion. How do tax morale and the threat with sanctions interact? Which is, in particular, the effect of sanctions that would not deter a risk neutral taxpayer (for the corresponding question regarding social value orientation and nondeterrent sanctions see Engel 2014)? Is tax morale crowded out, are both effects additive, or is there even crowding in? And how does the additional effect of a (potentially non-deterrent) threat with sanctions interact with the perceived fairness of the tax regime? We leave these questions for future research. 


\section{References}

Abeler, Johannes, Daniele Nosenzo And Collin Raymond (2016). Preferences for Truthtelling. https://papers.ssrn.com/sol3/papers.cfm?abstract id=2866381.

Abraham, Martin, Kerstin Lorek, Friedemann Richter and Matthias Wrede (2017). "Collusive Tax Evasion and Social Norms." International Tax and Public Finance 24(2): 179-197.

Allingham, Michael G and Agnar Sandmo (1972). "Income Tax Evasion. A Theoretical Analysis." Journal of Public Economics 1(3-4): 323-338.

Alm, JAmes (2012). "Measuring, Explaining, and Controlling Tax Evasion:. Lessons from Theory, Experiments, and Field Studies." International Tax and Public Finance 19(1): 54-77.

Alm, James, Betty R Jackson and Michael McKee (1992). "Estimating the Determinants of Taxpayer Compliance with Experimental Data." National Tax Journal 45: 107114.

Alm, James and Sarah Jacobson (2007). "Using Laboratory Experiments in Public Economics." National Tax Journal 60: 129-152.

Alm, James, Gary H McClelland and William D Schulze (1992). "Why Do People Pay Taxes?" Journal of Public Economics 48(1): 21-38.

Alm, James, Isabel Sanchez and Ana De Juan (1995). "Economic and Noneconomic Factors in Tax Compliance." Kyklos 48(1): 1-18.

Anderhub, Vital, Sebastian Giese, Werner GÜth, AntJe Hoffmann and Thomas Otto (2001). "Tax Evasion with Earned Income-an Experimental Study." Public Finance Analysis 58: 188-206.

Arad, Ayala And Ariel Rubinstein (2012). "The 11-20 Money Request Game. A Level-k Reasoning Study." American Economic Review 102(7): 3561-3573.

BAldRY, Jonathan C (1986). "Tax Evasion is not a Gamble. A Report on Two Experiments." Economics Letters 22(4): 333-335.

Bar-Gill, Oren and Christoph Engel (2018). "How to Protect Entitlements: An Experiment." Journal of Law and Economics 61: 525-553.

BAZART, CÉCILE AND AurÉLIE Bonein (2014). "Reciprocal Relationships in Tax Compliance Decisions." Journal of Economic Psychology 40: 83-102. 
BazArt, CÉcile AND AurÉlie Bonein (2017). "The Strength of the Symbol." Revue Économique(5): 829-841.

Bechtold, Stefan (2010). Die Grenzen zwingenden Vertragsrechts - ein rechtsökonomischer Beitrag zu einer Rechtsetzungslehre des Privatrechts. Tübingen, Mohr Siebeck.

BecKer, Winfried, Heinz-JÜRgen BÜChner And Simon SleEking (1987). "The Impact of Public Transfer Expenditures on Tax Evasion. An Experimental Approach." Journal of Public Economics 34(2): 243-252.

Bernasconi, Michele, Luca Corazzini And Raffaello Seri (2014). "Reference Dependent Preferences, Hedonic Adaptation and Tax Evasion. Does the Tax Burden Matter?" Journal of Economic Psychology 40: 103-118.

Bicchieri, Cristina And Erte Xiao (2009). "Do the Right Thing: But Only if Others Do So." Journal of Behavioral Decision Making 22(2): 191-208.

Blackwell, Calvin (2007). A Meta-Analysis of Tax Compliance Experiments. https://econpapers.repec.org/paper/aysispwps/paper0724.htm.

Blaufus, Kay, Jonathan Bob And Philipp E OtTo (2014). The Effect of Tax Privacy on Tax Compliance. An Experimental Investigation. http://papers.ssrn.com/sol3/papers.cfm?abstract id=2449217.

Blaufus, Kay, Jochen Hundsdoerfer, Martin Jacob and Matthias Sünwoldt (2016). "Does Legality Matter? The Case of Tax Avoidance and Evasion." Journal of Economic Behavior \& Organization 127: 182-206.

Bosco, Luigi And Luigi MitTone (1997). "Tax Evasion and Moral Constraints. Some Experimental Evidence." Kyklos 50(3): 297-324.

Bott, Kristina Maria, Alexander W Cappelen, Erik Sorensen and Bertil Tungodden (2017). You've Got Mail. A Randomised Field Experiment on Tax Evasion. https://papers.ssrn.com/sol3/papers.cfm?abstract id=3033775.

Bühren, Christoph And Thorben C Kundt (2014). "Does the Level of Work Effort Influence Tax Evasion? Experimental Evidence." Jahrbuch für Wirtschaftswissenschaften 65(2): 137-158.

Castro, Massimo Finocchiaro And Ilde Rizzo (2014). "Tax Compliance under Horizontal and Vertical Equity Conditions. An Experimental Approach." International Tax and Public Finance 21(4): 560-577. 
Chen, Daniel L, Martin Schonger And Chris WiCKens (2016). "oTree-An Open-source Platform for Laboratory, Online, and Field Experiments." Journal of Behavioral and Experimental Finance 9: 88-97.

Cialdini, Robert B., Carl A. Kallgren and Raymond R. Reno (1991). "A Focus Theory of Normative Conduct. A Theoretical Refinement and Reevaluation of the Role of Norms in Human Behaviour." Advances in Experimental Social Psychology 24: 201234.

Desmet, Pieter and Christoph Engel (2017). People Are Conditional Rule Followers. https://papers.ssrn.com/soL3/papers.cfm?abstract id=2969799.

Doerrenberg, PhilipP (2015). "Does the Use of Tax Revenue Matter for Tax Compliance Behavior?" Economics Letters 128: 30-34.

Doerrenberg, Philipp And Denvil Duncan (2014a). "Distributional Implications of Tax Evasion. Evidence from the Lab." Public Finance Review 42: 720-744.

Doerrenberg, PhilipP And Denvil Duncan (2014b). "Experimental Evidence on the Relationship between Tax Evasion Opportunities and Labor Supply." European Economic Review 68: 48-70.

Doerrenberg, Philipp And Andreas Peichl (2017). Tax Morale and the Role of Social Norms and Reciprocity. Evidence from a Randomized Survey Experiment. https://ideas.repec.org/p/zbw/zewdip/17045.html.

Durham, Yvonne, Tracy S Manly and Christina Ritsema (2014). "The Effects of Income Source, Context, and Income Level on Tax Compliance Decisions in a Dynamic Experiment." Journal of Economic Psychology 40: 220-233.

Elffers, Henk, Henry SJ Robben and Dick J Hessing (1992). "On Measuring Tax Evasion." Journal of Economic Psychology 13(4): 545-567.

Engel, Christoph (2014). "Social Preferences Can Make Imperfect Sanctions Work. Evidence from a Public Good Experiment." Journal of Economic Behavior \& Organization 108: 343-353.

FEHR, ERnSt And Klaus M. SChMidT (1999). "A Theory of Fairness, Competition, and Cooperation." Quarterly Journal of Economics 114: 817-868.

Filer, Randall K, Jan HanouseK, Tomas Lichard And Karine Torosyan (2016). 'Flattening'the Tax Evasion. Evidence from the Post-Communist Natural Experiment. https://papers.ssrn.com/sol3/papers.cfm?abstract id=2766557.

Fochmann, Martin, Nadja Müller and Michael Overesch (2018). Less Cheating? The Effects of Prefilled Forms on Compliance Behavior. 
https://papers.ssrn.com/sol3/papers.cfm?abstract id=3206410.

Fortin, Bernard, Guy Lacroix and Marie-Claire Villeval (2007). "Tax Evasion and Social Interactions." Journal of Public Economics 91(11): 2089-2112.

Gill, David And Rebecca Stone (2010). "Fairness and Desert in Tournaments." Games and Economic Behavior 69(2): 346-364.

Gillitzer, Christian And Peer EbBesen Skov (2016). "The Use of Third-party Information Reporting for Tax Deductions. Evidence and Implications from Charitable Deductions in Denmark." Oxford Economic Papers.

Gneezy, Uri, Agne Kajackaite and Joel Sobel (2018). "Lying Aversion and the Size of the Lie." American Economic Review 108(2): 419-453.

Güth, Werner, Sabine Strauß and Matthias Sutter (2002). Tax Evasion and State Productivity. An Experimental Study. http://ideas.repec.org/p/esi/discus/200237.html.

Hallsworth, Michael (2014). "The Use of Field Experiments to Increase Tax compliance." Oxford Review of Economic Policy 30(4): 658-679.

Heinemann, Friedrich And Martin G Kocher (2013). "Tax Compliance under Tax Regime Changes." International Tax and Public Finance 20(2): 225-246.

Holt, Charles A. And Susan K. Laury (2002). "Risk Aversion and Incentive Effects." American Economic Review 92: 1644-1655.

Jacobsen, Catrine and Marco Piovesan (2014). Tax me if you Can. An Artefactual Field Experiment on Dishonesty. http://okonomi.foi.dk/workingpapers/WPpdf/WP2015/IFRO WP 2015 05.pdf

Jimenez, Peggy And Govind S Iyer (2016). "Tax Compliance in a Social Setting. The Influence of Social Norms, Trust in Government, and Perceived Fairness on Taxpayer Compliance." Advances in Accounting 34: 17-26.

Johnson, ERIC J. AND Daniel GoldStein (2003). "Do Defaults Save Lives?" Science 302: 1338-1339.

KajacKaite, Agne (2018). "Lying about Luck versus Lying about Performance." Journal of Economic Behavior \& Organization 153: 194-199.

Kimbrough, ERIK O And AleXander Vostroknutov (2016). "Norms Make Preferences Social." Journal of the European Economic Association 14: 608-638. 
KIRCHLER, ERICH (2007). The Economic Psychology of Tax Behaviour, Cambridge University Press.

Kleven, Henrik Jacobsen, Martin B Knudsen, Claus Thustrup Kreiner, Søren PederSEN AND EMMANUEL SAEz (2011). "Unwilling or Unable to Cheat? Evidence from a Tax Audit Experiment in Denmark." Econometrica 79(3): 651-692.

Konow, James (2000). "Fair Shares. Accountability and Cognitive Dissonance in Allocation Decisions." American Economic Review 90(4): 1072-1091.

Konow, JAmes (2003). "Which is the Fairest One of All? A Positive Analysis of Justice Theories." Journal of Economic Literature 41: 1186-1237.

Kotakorpi, Kaisa And Jani-Petri LaAmanen (2016). Prefilled Income Tax Returns and Tax Compliance. Evidence from a Natural Experiment. http://tampub.uta.fi/handle/10024/98986.

KrupKa, ERIN L. AND RoBerto A. Weber (2013). "Identifying Social Norms Using Cordination Games. Why Does Dictator Game Sharing Vary?" Journal of the European Economic Association 11(3): 495-524.

Lefebvre, Mathieu, Pierre Pestieau, Arno Riedl and Marie Claire Villeval (2015). "Tax Evasion and Social Information: an Experiment in Belgium, France, and the Netherlands." International Tax and Public Finance 22(3): 401-425.

Mittone, Luigi (2006). "Dynamic behaviour in Tax Evasion. An Experimental Approach." Journal of Socio-Economics 35(5): 813-835.

Murphy, Ryan O. And Kurt A. AcKermann (2014). "Social Value Orientation: Theoretical and Measurement Issues in the Study of Social Preferences." Personality and Social Psychology Review 18: 13-41.

Pickhardt, Michael and Aloys Prinz (2014). "Behavioral Dynamics of Tax Evasion. A Survey." Journal of Economic Psychology 40: 1-19.

Slemrod, Joel (2016). Tax Compliance and Enforcement. New Research and its Policy Implications. http://ssrn.com/abstract=2726077.

Spicer, Michael W AND LeE A Becker (1980). "Fiscal Inequity and Tax Evasion. An Experimental Approach." National Tax Journal 33: 171-175.

Torgler, Benno (2002). "Speaking to Theorists and Searching for Facts. Tax Morale and Tax Compliance in Experiments." Journal of Economic Surveys 16(5): 657-683.

Torgler, Benno (2007). Tax Compliance and Tax Morale. A Theoretical and Empirical Analysis, Edward Elgar Publishing. 
Wakolbinger, Florian and Stefan Daniel Haigner (2009). "Peer Advice in a Taxevasion Experiment." Economics Bulletin 29(3): 1653-1669. 


\title{
Appendix
}

\author{
Instructions
}

Welcome!

You are going to take part in an experiment on economic decision making that will allow you to earn some money. During the experiment, you will be asked to make decisions, but you will retain your anonymity. The amount of money you will earn will depend on the decisions that you will make. In addition, you will receive a payment of $€ 3$ in exchange for your participation.

During the experiment, all the earnings will be denominated in ECU (experimental currency units). At the end of the experiment, your earnings in euro will be determined by the ECU/€ exchange rate:

$$
20 \mathrm{ECU}=€ 1 \text {. }
$$

During the experiment, you will not be allowed to talk to the other participants. If you do not follow this rule, you will be asked to leave the experiment and you will not receive any payment. If you have any questions, or need help, please raise your hand and a member of the experimental team will assist you.

The experiment consists of several parts, each of which is separated from the other parts. This means that your payments and decisions in one part of the experiment do not affect payments in subsequent parts. At the end of the experiment, you will receive a payment equal to the sum of the payments received in each part.

Below are instructions for the first part of today's experiment.

\section{First part instructions (Rule following by isolated individuals)}

In this experiment, you assume the role of a tax payer. In each of 10 rounds, you will receive an income. In each round, you will be required to pay a tax, but you can decide to evade part of this tax, or even all of it. The amount of tax you decide to pay will be used to finance future laboratory experiments.

To facilitate your reporting, in each round, the tax you are required to pay will be prefilled. However, you are free to change the amount as you like (and hence pay between $0 \%$ and $100 \%$ of the tax you are required to pay).

In every round, your earning in ECU is calculated as follows: the income you received minus the tax you decided to pay. Thus, the total gain in ECU for this first part of the experiment is equal to the sum of the incomes you received during each of the 10 rounds, minus the sum of the taxes you have decided to pay in the same 10 rounds.

\section{Instructions second part (main experiment)}

The second part of the experiment is identical to the first, except that you now are a member of a randomly composed group of 3 participants. Full anonymity is still guaranteed. Hence your identity will be not communicated to the other members of your group and you will never learn the identity of the other members of your group.

During this second part of the experiment you will be provided with information about the income, and the stipulated tax, for each member of your group.

This part of the experiment also lasts 10 rounds. In each round you will receive an income. In each round, you will be required to pay a tax, but you can decide to evade part of this tax, or even all of it. The amount of tax you decide to pay will be used to finance future laboratory experiments. 
To facilitate your reporting, in each round, the tax you are required to pay will be prefilled. However, you are free to change the amount as you like (and hence pay between $0 \%$ and $100 \%$ of the tax you are required to pay). You will also be provided with information on income and tax that each member of your group is required to pay in each round.

In every round, your earning in ECU is calculated as follows: the income you received minus the tax you decided to pay. Thus, the total gain in ECU for this second part of the experiment is equal to the sum of the incomes you received during each of the 10 rounds, minus the sum of the taxes you have decided to pay in the same 10 rounds.

\section{Instructions part 3 (normative beliefs)}

In this part of the experiment, we ask you to rate the social appropriateness of choices you and the remaining participants might have made in the previous part of the experiment. At the end of the entire experiment, the computer will randomly select one of the three situations, and one of the 11 possibilities for a choice on this task. If the choice you have made is the same as the choice that has been made most frequently by all participants of the secsion (including yourself), you will receive an additional bonus of 20 ECU. Should two or more choices have been equally frequent on this task, you will receive the bonus if you have made one of them.

Assume there are 3 participants who earn 5, 10 and 15 ECU.

(Lump sum_tax treatment) Each has to pay a tax of 2 ECU

(Proportional tax treatment) Those with an income of $5 \mathrm{ECU}$ are required to pay a tax of $1 \mathrm{ECU}$. Those with an income of $10 \mathrm{ECU}$ are required to pay a fee of $2 \mathrm{ECU}$. Those with an income of $15 \mathrm{ECU}$ are required to pay a fee of $3 \mathrm{ECU}$.

(Progressive tax treatment) Those with an income of $5 \mathrm{ECU}$ are required to pay a tax of 0,571 ECU. Those with an income of $10 \mathrm{ECU}$ are required to pay a fee of 2 ECU. Those with an income of $15 \mathrm{ECU}$ are required to pay a fee of 3,429 ECU.

(Lump sum tax treatment) How socially appropriate is it that an individual with an income of $15 \mathrm{ECU}$ and a requested tax to pay equal to $2 \mathrm{ECU}$, decides to pay respectively:

(Proportional treatment) How socially appropriate is it that an individual with an income of $15 \mathrm{ECU}$ and a requested tax to pay equal to $3 \mathrm{ECU}$, decides to pay respectively:

(Progressive tax treatment) How socially appropriate is it that an individual with an income of $15 \mathrm{ECU}$ and a requested tax to pay equal to $3,429 \mathrm{ECU}$, decides to pay respectively:

$0 \%$ of the requested tax - very appropriate I_ somewhat appropriate I_ somewhat inappropriate |_| very inappropriate|_|

$10 \%$ of the requested tax - very appropriate I_l somewhat appropriate I_l somewhat inappropriate |_| very inappropriate|_| 
$20 \%$ of the requested tax - very appropriate I $\mid$ somewhat appropriate |_

somewhat inappropriate |_| very inappropriate|_

$30 \%$ of the requested tax - very appropriate | _ somewhat appropriate |_

somewhat inappropriate |_| very inappropriate|_|

$40 \%$ of the requested tax - very appropriate | _ somewhat appropriate |_|

somewhat inappropriate |_| very inappropriate|_|

$50 \%$ of the requested tax - very appropriate |_l somewhat appropriate |_l

somewhat inappropriate |_| very inappropriate|_|

$60 \%$ of the requested tax - very appropriate |_l somewhat appropriate |_|

somewhat inappropriate |_| very inappropriate|_|

$70 \%$ of the requested tax - very appropriate |_| somewhat appropriate |_l

somewhat inappropriate |_| very inappropriate|_|

$80 \%$ of the requested tax - very appropriate I $\mid$ somewhat appropriate $\left|\_\right|$

somewhat inappropriate |_| very inappropriate|_|

$90 \%$ of the requested tax - very appropriate |_| somewhat appropriate |_l

somewhat inappropriate |_| very inappropriate|_|

$100 \%$ of the requested tax - very appropriate | _ somewhat appropriate |_|

somewhat inappropriate |_| very inappropriate|_|

(Lump sum/Proportional/Progressive tax treatments)How socially appropriate is it that an individual with an income of $10 \mathrm{ECU}$ and a requested tax to pay equal to 2 ECU, decides to pay respectively:

$0 \%$ of the requested tax - very appropriate I_ somewhat appropriate I_ somewhat inappropriate |_| very inappropriate|_|

$10 \%$ of the requested tax - very appropriate I_| somewhat appropriate |_l 
somewhat inappropriate |_| very inappropriate|_|

$20 \%$ of the requested tax - very appropriate $\mid \_$somewhat appropriate $\left|\_\right|$

somewhat inappropriate |_| very inappropriate|_|

$30 \%$ of the requested tax - very appropriate I_ somewhat appropriate I $\mid$

somewhat inappropriate |_| very inappropriate|_

$40 \%$ of the requested tax - very appropriate | _ somewhat appropriate I_

somewhat inappropriate |_| very inappropriate|_|

$50 \%$ of the requested tax - very appropriate I_ somewhat appropriate I_l

somewhat inappropriate |_| very inappropriate|_

$60 \%$ of the requested tax - very appropriate $\mid \_$somewhat appropriate $\left|\_\right|$

somewhat inappropriate |_| very inappropriate|_|

$70 \%$ of the requested tax - very appropriate I_ somewhat appropriate |_|

somewhat inappropriate |_| very inappropriate|_|

$80 \%$ of the requested tax - very appropriate | $\mid$ somewhat appropriate |_

somewhat inappropriate |_| very inappropriate|_|

$90 \%$ of the requested tax - very appropriate I_ somewhat appropriate |_l

somewhat inappropriate |_| very inappropriate|_|

$100 \%$ of the requested tax - very appropriate |_l somewhat appropriate |_|

somewhat inappropriate |_| very inappropriate|_|

(Lump sum tax treatment) How socially appropriate is it that an individual with an income of $5 \mathrm{ECU}$ and a requested tax to pay equal to $2 \mathrm{ECU}$, decides to pay respectively:

(Proportional treatment) How socially appropriate is it that an individual with an income of $5 \mathrm{ECU}$ and a requested tax to pay equal to $1 \mathrm{ECU}$, decides to pay respectively: 
(Progressive tax treatment) How socially appropriate is it that an individual with an income of $5 \mathrm{ECU}$ and a requested tax to pay equal to $0,571 \mathrm{ECU}$, decides to pay respectively:

$0 \%$ of the requested tax - very appropriate $\left|\_\right|$somewhat appropriate |_|

somewhat inappropriate |_| very inappropriate|_|

$10 \%$ of the requested tax - very appropriate $\left|\_\right|$somewhat appropriate $\left|\_\right|$

somewhat inappropriate |_| very inappropriate|_|

$20 \%$ of the requested tax - very appropriate |_| somewhat appropriate $\left|\_\right|$

somewhat inappropriate |_| very inappropriate|_|

$30 \%$ of the requested tax - very appropriate |_| somewhat appropriate |_|

somewhat inappropriate |_| very inappropriate|_|

$40 \%$ of the requested tax - very appropriate |_| somewhat appropriate |_|

somewhat inappropriate |_| very inappropriate|_|

$50 \%$ of the requested tax - very appropriate $\left|\_\right|$somewhat appropriate |_|

somewhat inappropriate |_| very inappropriate|_|

$60 \%$ of the requested tax - very appropriate |_| somewhat appropriate |_|

somewhat inappropriate |_| very inappropriate|_|

$70 \%$ of the requested tax - very appropriate |_| somewhat appropriate |_|

somewhat inappropriate |_| very inappropriate|_|

$80 \%$ of the requested tax - very appropriate $\left|\_\right|$somewhat appropriate $\left|\_\right|$

somewhat inappropriate |_| very inappropriate|_

$90 \%$ of the requested tax - very appropriate $\left|\_\right|$somewhat appropriate $\left|\_\right|$

somewhat inappropriate |_| very inappropriate|_|

$100 \%$ of the requested tax - very appropriate $\left|\_\right|$somewhat appropriate $\left|\_\right|$

somewhat inappropriate |_| very inappropriate|_| 


\section{Instructions part 4 (descriptive beliefs)}

(Lump sum tax treatment) In this experimental session, 6 participants had an income equal to $5 \mathrm{ECU}$ and a requested tax to pay equal to $2 \mathrm{ECU}$. Other 6 participants had an income of $10 \mathrm{ECU}$ and a requested tax to pay equal to $2 \mathrm{ECU}$. Finally, 6 participants had an income equal to $15 \mathrm{ECU}$ and a requested tax to pay equal to 2 ECU.

(Proportional tax treatment) In this experimental session, 6 participants had an income equal to $5 \mathrm{ECU}$ and a requested tax to pay equal to $1 \mathrm{ECU}$. Other 6 participants had an income of $10 \mathrm{ECU}$ and a requested tax to pay equal to $2 \mathrm{ECU}$. Finally, 6 participants had an income equal to $15 \mathrm{ECU}$ and a requested tax to pay equal to $3 \mathrm{ECU}$.

(Progressive tax treatment) In this experimental session, 6 participants had an income equal to $5 \mathrm{ECU}$ and a requested tax to pay equal to $0,571 \mathrm{ECU}$. Other 6 participants had an income of $10 \mathrm{ECU}$ and a requested tax to pay equal to $2 \mathrm{ECU}$. Finally, 6 participants had an income equal to $15 \mathrm{ECU}$ and a requested tax to pay equal to 3,429 ECU.

How much do you believe have participants with income equal to $5 \mathrm{ECU}$ on average declared (averaging over all rounds) |_|?

How much do you believe have participants with income equal to $10 \mathrm{ECU}$ on average declared (averaging over all rounds) |_|?

How much do you believe have participants with income equal to $15 \mathrm{ECU}$ on average declared (averaging over all rounds) |_|?

At the end of this part of the experiment, with equal probability either of these three questions will be singled out to be payoff relevant. If you get this number (rounded to the nearest integer) exactly right, you earn an additional $20 \mathrm{ECU}$. If your estimate is 1 unit above or below the true average, you earn an additional $10 \mathrm{ECU}$. If your estimate is more than 1 unit above or below the true average, you will not receive any additional compensation.

\section{Instructions part 5 (risk elicitation)}

In this part, you visualize 10 rows. For each of the rows, you have to choose between Option A and Option B. After you have made your choice in each of the 10 rows, the computer will randomly choose one of the rows to be payoff relevant. Your earnings will be defined based on the outcome of the lottery that you chose on the randomly chosen row. This earning will be added to the earnings previously accumulated. 


\begin{tabular}{|c|c|c|c|}
\hline Riga & A & & B \\
\hline 1 & $1 / 10$ vinci 20 UMS e $9 / 10$ vinci 16 UMS & $\mathrm{A} \bigcirc \mathrm{B}$ & 1/10 vinci 38.5 UMS e $9 / 10$ vinci 1 UMS \\
\hline 2 & $2 / 10$ vinci 20 UMS e $8 / 10$ vinci 16 UMS & $\mathrm{A} \bigcirc \mathrm{B}$ & 2/10 vinci 38.5 UMS e 8/10 vinci 1 UMS \\
\hline 3 & $3 / 10$ vinci 20 UMS e $7 / 10$ vinci 16 UMS & $A \bigcirc B$ & 3/10 vinci 38.5 UMS e 7/10 vinci 1 UMS \\
\hline 4 & 4/10 vinci 20 UMS e 6/10 vinci 16 UMS & $A \bigcirc B$ & 4/10 vinci 38.5 UMS e 6/10 vinci 1 UMS \\
\hline 5 & $5 / 10$ vinci 20 UMS e $5 / 10$ vinci 16 UMS & $A \bigcirc B$ & $5 / 10$ vinci 38.5 UMS e 5/10 vinci 1 UMS \\
\hline 6 & $6 / 10$ vinci 20 UMS e $4 / 10$ vinci 16 UMS & $\mathrm{A} \bigcirc \mathrm{B}$ & $6 / 10$ vinci 38.5 UMS e 4/10 vinci 1 UMS \\
\hline 7 & $7 / 10$ vinci 20 UMS e $3 / 10$ vinci 16 UMS & $A \bigcirc B$ & $7 / 10$ vinci 38.5 UMS e $3 / 10$ vinci 1 UMS \\
\hline 8 & $8 / 10$ vinci 20 UMS e $2 / 10$ vinci 16 UMS & $A \bigcirc B$ & 8/10 vinci 38.5 UMS e 2/10 vinci 1 UMS \\
\hline 9 & $9 / 10$ vinci 20 UMS e $1 / 10$ vinci 16 UMS & $A \bigcirc B$ & 9/10 vinci 38.5 UMS e 1/10 vinci 1 UMS \\
\hline 10 & 10/10 vinci 20 UMS e 0/10 vinci 16 UMS & $\bigcirc \bigcirc \bigcirc$ & 10/10 vinci 38.5 UMS e 0/10 vinci 1 UMS \\
\hline & & PROSEGUI & \\
\hline
\end{tabular}

\section{Instructions part 6 (Social Value Orientation)}

In this phase you will make a series of decisions about allocating resources (ECU) between yourself and another person. During this phase your earnings will be converted to $€$ according to a new exchange rate

$$
40 \mathrm{ECU}=1 € .
$$

For each of the following items, please indicate the distribution you prefer most by clicking the respective position.

\begin{tabular}{|l|c|c|c|c|c|c|c|c|c|}
\hline You receive & 85 & 85 & 85 & 85 & 85 & 85 & 85 & 85 & 85 \\
\hline Other receives & 85 & 76 & 66 & 59 & 50 & 41 & 33 & 24 & 15 \\
\hline
\end{tabular}

There are no right or wrong answers, this is all about personal preferences.

You will repeat this task 6 times (with different numbers).

After all participants have made their decisions you will be randomly assigned to be an "Allocator" or a "Recipient". If you are an allocator then one of your decisions (ran- 
domly chosen) will determine your payoff and the payoff of another participant. If you are a recipient then your payoff will be determined by one of the other participants.

\section{Calculation of Progressive Tax}

We assume utility to be defined by (8), and $r=.5$. We further assume a subsistence income of 3 . Across treatments, we hold total tax returns constant at 6 , provided that all taxes are paid as due. Consequently we need tax rates such that $\hat{t}_{l}+\hat{t}_{m}+\hat{t}_{h}=6$. We further want to hold $\hat{t}_{m}=2$ constant across treatments. Given our assumptions about the utility function, and writing $\dot{u}_{k}=u\left(e_{k}-3\right)$ for utility from the taxable income, we have $\Delta \dot{u}_{m}=u(7)-u(5)=.1548$. We calculate $\hat{t}_{l}$ such that $\Delta \dot{u}_{l}=u(2)-$ $u\left(2-\hat{t}_{l}\right)=.1548$, and $\hat{t}_{h}$ such that $\Delta \dot{u}_{h}=u(12)-u\left(12-\hat{t}_{h}\right)=.1548$. This gives us $\hat{t}_{l}=.571, \hat{t}_{h}=3.429$. 